\title{
Uterotonic Effects of Aqueous and Methanolic Extracts of Lannea Acida in Wistar Rats: An in Vitro Study.
}

esther simo ngadjui ( $\nabla$ estherngadjui@yahoo.fr )

Universite de Dschang Faculte des Sciences https://orcid.org/0000-0002-2971-7537

Jibril Yves Kouam

Universite de Dschang

Georges Romeo Fozin Bonsou

Universite de Dschang

Aimé Césaire Tetsatsi Momo

Universite de Dschang

Patrick Brice Defo Deeh

Universite de Dschang

Modeste Wankeu-Nya

Universite de Dschang

Telesphore Benoit Nguelefack

Universite de Dschang

Pierre Watcho

Universite de Dschang

Research

Keywords: Lannea acida, calcium, uterine contraction, in vitro, rats

Posted Date: August 6th, 2020

DOI: https://doi.org/10.21203/rs.3.rs-52315/v1

License: (c) (i) This work is licensed under a Creative Commons Attribution 4.0 International License.

Read Full License

Version of Record: A version of this preprint was published at Reproductive Sciences on January 21st, 2021. See the published version at https://doi.org/10.1007/s43032-021-00465-x. 


\section{Abstract}

Background: Lannea acida (Anacardiaceae), commonly called Kikié in the Noun division (WestCameroon), is a tree whose bark is used locally to solve difficult childbirth. This study aimed to evaluate the in vitro uterotonic effects of aqueous and methanolic extracts of L. acida in female Wistar rats. Uterine strips isolated from female rats pretreated $(48 \mathrm{~h})$ with oestradiol $(5 \mu \mathrm{g})$ were mounted in a singleorgan bath containing a well aerated and thermostated De Jalon solution $\left(37^{\circ} \mathrm{C}\right)$. The effects of $\mathrm{L}$. acida extracts were recorded in a non-cumulative manner after application. The effect of the methanolic extract (the most active extract) was monitored in the presence of atosiban (a competitive antagonist of oxytocin receptors), atropine (a specific type 3 muscarinic receptor antagonist), nifedipine (an L-type calcium channel antagonist) and 2-Aminoethoxydiphenyl borate (2-ADB, a specific antagonist of inositol 1,4,5triphosphate receptors type 1), and in calcium-free medium containing EGTA.

Results: L. acidainduced uterine contraction in a concentration-dependent manner with the methanolic extract (1.506 $\pm 0.032 \mathrm{gf})$ being the most effective. Administration of atosiban $(2 \mu \mathrm{mol} / \mathrm{l})$, atropine (1 $\mu \mathrm{mol} / \mathrm{l})$, nifedipine $(5 \mu \mathrm{mol}), 2-A P B(100 \mu \mathrm{mol})$, and calcium free medium containing EGTA (2 mmol) reduced the contractile effect of $L$. acida. Complete inhibition was observed with nifedipine, 2-APB, and calcium free medium containing EGTA.

Conclusions: These results suggest that $L$. acida possesses an uterotonic effect mediated through oxytocin receptors with mobilization of extracellular calcium.

\section{Background}

Parturition is the process ofdelivery of a fully-grown fetus on the completion of the normal pregnancy period. This biological process is characterized by an increase in myometrial contractility and the dilatation of the uterine cervix [1]. In fact, as term approaches, the quiescent uterus becomes activated byestrogens. This leads to increased expression of various contraction-associated proteins (CAPs) such as prostaglandin and oxytocin receptors [2]. Also, an increase in gap junction formation between adjacent myometrial cells allows electrical synchrony within the myometrium and ensures effective coordination of contractions [3]. During labor process, the frequency and intensity of myometrial smooth muscle contractions are essential contributing factors to normal delivery [4]. In women with slow and/or weak uterine activity during labor, uterotonic molecules (oxytocin and prostaglandins) are regularly used $[5,6]$. In extreme cases, caesarian sections can be required [7]. However, these modern technics are limited due to postpartum bleeding commonly associated to uterotonic compoundsand financial and esthetic consequences of the surgical solution[8]. Furthermore, in developing countries where the accessibility of health services is limited, people largely rely on medicinal plant for primary health problems [9].

Many medicinal plants with uterotonic properties have been reported. These include among other Newbouldia laevis [10], Ananas comosus [11] and Foeniculum vulgare [12]. Lannea acida (Anacardiaceae 
family), commonly called Kikié in the Noun Division (West-Cameroon) is a small deciduous tree of about 8 to 12 meters height. The decoction ofitsstem barks is traditionally used as fertility enhancer and at late gestational stage to facilitate parturition. Scientific evidences showed that this plant possesses androgenic [13], estrogenic [14] and contractile properties in isolated rat vas deferens and seminal vesicles [15]. Phytochemical screening of this plant revealed the presence of alkaloids, glycosides and tannins compounds $[16,17]$. However, less is known on the effects of this plant on uterine contractility in rats. This study was therefore undertaken to determine the effect of L. acida on uterine activity in healthy non-pregnant rat and its mechanism of action.

\section{Results}

\section{Effects of the aqueous and methanolic extracts of L. acida on uterine contractility}

A dose-dependent contractile effect on the rat myometrial strips was recorded after application of aqueous extract of $L$. acida (Fig. 1A). On the contrary, the effect of methanolic extract was not dosedependent (Fig. 1B). Indeed, the maximum contractile effect was observed at moderate concentration $(2.18 \mathrm{mg})$ while the highest concentration $(4.36 \mathrm{mg})$ was less active. As shown in Fig. 1C, the contraction force increased gradually after the application of the aqueous extract of $L$. acida. In the uterus samples treated with the methanolic extract of $L$. acida, the contraction force increased at low $(1.09 \mathrm{mg} / \mathrm{ml})$ and moderate $(2.18 \mathrm{mg} / \mathrm{ml})$ concentrations, but decreased at high concentrations $(3.27$ and $4.36 \mathrm{mg} / \mathrm{ml})$. The methanolic extract was more effective at low concentrations while the aqueous extract produced the highest effect at high concentration (Fig. 1A, B, C).

\section{Relative potency of the aqueous and methanolic extracts of L. acida and other uterotonincs}

The effect of $L$. acida extracts and agonists on the relative potency of rat uterus is shown in Table 1 . The tension recorded after application of oxytocin was increased by $24.17 \%$ and $15.41 \%$ compared to aqueous and methanolic extracts of $L$. acida respectively. Acetylcholine also increased the uterus tension by $28.29 \%$ and $20 \%$ compared to aqueous and methanolic extracts of $L$. acida respectively. The uterus tension increased by $50.49 \%$ and $44.77 \%$ in the samples treated with potassium chloride, compared to aqueous and methanolic extracts of $L$. acida respectively (Table 1 ). Potassium chloride was the most effective drug. 
Table 1

Relative potency of $L$. acida extracts compared to other uterotonics

\begin{tabular}{|ll|}
\hline Treatments & Tension (gf) \\
\hline Methanolic extract of L. acida & $1.506 \pm 0.032$ \\
\hline Aqueous extract of L. acida & $1.680 \pm 0.230$ \\
\hline Oxytocin & $1.986 \pm 0.063$ \\
\hline Acetylcholine & $2.100 \pm 0.087$ \\
\hline Potassium chloride & $3.042 \pm 0.041$ \\
\hline
\end{tabular}

\section{Effects of some antagonists on uterine contraction induced by plant extracts and agonists}

\section{Effect of atosiban and atropine on uterine contraction induced by L. acida}

Oxytocin, acetylcholine and $L$. acida induced uterine contraction after application. The contractile effects of oxytocin were totally inhibited by atosiban (Fig. 2A). Atosiban also inhibited the contractile effect of the methanolic extract of $L$. acida. However, the second administration of the plant extract (before washout period) caused moderated contractions of the uteri strips (Fig. 2B). The force of contraction increased significantly $(\mathrm{p}<0.05)$ after oxytocin and L. acida applications compared to control (Fig. $2 \mathrm{C})$.

The contractile effect of acetylcholine was totally inhibited after atropine (a specific type 3 muscarinic receptor antagonist) application (Fig. 2D). Additionally, atropine partially inhibited the contractile effect of the methanolic extract of $L$. acida (Fig. 2E). The force of contraction recorded after atropine injection was significantly $(p<0.05)$ elevated compared to control (Fig. $2 F)$.

\section{Effect of nifedipine and $\mathrm{Ca}^{2+}$ free medium with EGTA on uterine contraction induced by L. acida}

The contractile effects of $\mathrm{KCl}$ and methanolic extract of $L$. acida were completely abolished in the presence of nifedipine ( $5 \mu \mathrm{mol}$, an L-type calcium receptor antagonist) (Fig. 3A and B). The maximum contraction forces of $\mathrm{KCl}$ and $L$. acida were reduced significantly $(\mathrm{p}<0.05)$, compared to control (Fig. $3 \mathrm{C})$. Compare to the effect in De Jalon solution, acetylcholine or $L$. acida had no contractile effect in calcium free medium with $2 \mathrm{mMol} / \mathrm{I}$ of EGTA (Fig. 4A-C). 


\section{Effect of 2-aminoethoxydiphenyl borate (2-APB) on uterine contractions induced by oxytocin and $\mathrm{L}$. acida}

The contractile effect of oxytocin and L. acida on uterine smooth muscle was significantly $(p<0.05)$ inhibited by 2-APB (a specific antagonist of inositol 1,4,5-triphosphate receptors type 1 ) with the Emax values $14.82 \pm 3.64 \%$ and $9.53 \pm 1.66 \%$ respectively (Fig. $5 \mathrm{~A}-\mathrm{C}$ ).

\section{Discussions}

This study demonstrated the in vitro uterotonic effect of aqueous and methanolic extracts of L. acida, which may justified its traditional used to facilitate parturition. The uterine strips isolated from rats pretreated (subcutaneously) with17- $\beta$-estradiol were used in this work because of its high sensitivity to uterotonic agents [2]. L. acida extracts $(1.09$ to $4.36 \mathrm{mg} / \mathrm{ml})$ stimulated uterine contraction with a maximal effect obtained at a concentration of $2.18 \mathrm{mg} / \mathrm{ml}$ with the methanolic extract and $4.36 \mathrm{mg} / \mathrm{ml}$ with the aqueous extract. Comparatively, the methanolic extract of $L$. acida was more effective at low concentrations $(1.09$ and $2.18 \mathrm{mg} / \mathrm{ml}$ ) while the aqueous extract had its highest effect at high concentrations ( 3.27 and $4.36 \mathrm{mg} / \mathrm{ml}$ ). Over $2.18 \mathrm{mg} / \mathrm{ml}$ of methanolic extract in the medium, the contraction force decreased with increasing concentration. This adverse effect carried out in vitro could be attributed to the high concentration of the active principle such as alkaloids, saponins and flavonoids [17] in methanolic extract than the aqueous extract that can trigger an internalization or desensitization of the uterine receptors. Recently, it has been demonstrated that alkaloids and saponins induce contractile activities on smooth muscle [22, 23]. The alkaloids (Imperialine-3 $\beta$-D-glucoside) are known for their ability to contract uterine smooth muscle in contrast to the flavonoids (spinosine) that relax it [24]. Apart from L. acida (Anarcadiceae) other Anacardiaceae species including Spondias mombin [24] were also reported to stimulate uterine contraction $(0.75 \mathrm{mg} / \mathrm{ml})$, suggesting that the uterotonic effect is common to the Anacardiaceae family. Similar studies using rat $[12,25]$ and mouse [26] uterine strip have led to conclude that bioactive compounds found in L. acida are responsible for the contractile effects. In the current study, the maximal concentration $(2.18 \mathrm{mg} / \mathrm{ml})$ which gives the maximal effect is highest than the maximal concentration $(1.6 \mathrm{mg} / \mathrm{ml}$ and $2 \mathrm{mg} / \mathrm{ml})$ used respectively by Watcho [19] and salleh and Ahmad [27].

Like oxytocin, acetylcholine and potassium chloride which are good standard uterotonic agents, L. acida induced a concentration-dependent contractile effect. Despite several pharmacological and molecular studies on the elucidation of signaling pathways including metabotropic receptors [28], the mechanism of action with the most active extract (methanol) was carried out using atosiban (a competitive antagonist of oxytocin receptors) and atropine (a non-competitive antagonist of muscarinic channels) which are the major influence of extracellular calcium in the uterus strips. The contractile effect of the methanolic extract of $L$. acida was inhibited after atosiban $(2 \mu \mathrm{mol})$ or atropine $(1 \mu \mathrm{mol})$ application. Our findings suggest that $L$. acida-induced uterine contraction was mediated mainly via the oxytocin receptor as evidenced by the highest degree of inhibition of the atosiban while the lowest inhibition by atropine 
suggests that $L$. acida binding to the muscarinic receptors produced the least degree of contraction. These results are similar to the action observed by Watcho et al. [19] and Salleh and Ahmad [27], which showed that $F$. asperifolia and $F$. deltoidea respectively increase the contractile activity of rat uterine smooth muscle via multiple membrane receptors. The mechanism of action of stimulants depends mainly on pharmaco-mechanical coupling since membrane depolarization receptors appear to belong tothe G-protein family. Activation of the receptor which is coupled to $\mathrm{G}$ protein alpha stimulates uterine contraction by activating the phospholipase $\mathrm{C} / \mathrm{Ca}^{2+}$ dependent pathway [29]. G protein-coupled membrane receptors mobilize extracellular calcium via L-type calcium channels activated by DAG/PKC and/or intracellular calcium via IP3 receptors [30]. In addition, acetylcholine opens ion channels without depolarization of membrane while $\mathrm{KCl}$ induced contraction by depolarizing membrane which causes the influx of $\mathrm{Ca}^{2+}[31] . \mathrm{Ca}^{2+}$ then binds to calmodulin, which activates the myosin light chain kinase leading to phosphorylation of myosin light chains, triggering contraction [32].

In order to verify the involvement of L-type calcium channels and in turn the involvement of extracellular calcium in the mechanism of action of $L$. acida, a test with nifedipine and in free- $\mathrm{Ca}^{2+} \mathrm{De}$ Jalon with 2 mM EGTA were performed using potassium chloride and acetylcholine. Nifedipine ( $1 \mu \mathrm{Mol})$, an L-type calcium channel antagonist, suppressed the stimulatory effects of $L$. acida. Though all contractions of $L$. acida or acetylcholine were abolished in free-Ca ${ }^{2+}$ De Jalon with 2 mM EGTA after 30 minutes. In myometrial smooth muscle, calcium is sequestered in caveolae and recycles through L-type $\mathrm{Ca}^{2+}$ channels. The system can recycle $\mathrm{Ca}^{2+}$ efficiently between the caveolae and the SR using L-type $\mathrm{Ca}^{2+}$ channels and $\mathrm{IP}_{3}$ mediated $\mathrm{Ca}^{2+}$ release from the SR (by acetylcholine) [33]. These results suggest that $L$. acida could mobilize extracellular calcium by stimulating L-type calcium channels receptors.

Given the intracellular origin of calcium in the uterine smooth muscle contraction process, an additive experiment was performed using 2-APB, a non-specific type 1 IP3 receptor [34]. Because 2-APB inhibited the contractile effects of $L$. acida and oxytocin, we can therefore suggest that these drugs act through IP3 pathway. Moreover, the inhibitory effect of atosiban suggests that $L$. acida act through oxytocin receptors and mostly depend of extracellular calcium. Nevertheless, the contraction produced does not depend solely on extracellular $\mathrm{Ca}^{2+}$ as evident from the total inhibition on Emax by 2-APB.

Oxytocin binds to its $\mathrm{G}$ protein-coupled receptor and activates phospholipase C (PLC), which in turn increases inositol-trisphosphate (IP3) and diacylglycerol (DAG) levels. DAG induced extracellular $\mathrm{Ca}^{2+}$ influx through voltage-operate channels such as L-type calcium channel. IP3 activates the IP3 receptor at the sarcoplasmic reticulum membrane which release $\mathrm{Ca}^{2+}$ into the cytosol and amplify contractions [35]. Since 2-APB inhibits the contractile effect of $L$. acida, 2-APB may interact with TRPC and IP3 receptors [36] because Inositol 1,4,5-triphosphate activates TRPC3 channels and increases extracellular $\mathrm{Ca}^{2+}$ influx in smooth muscle cells [35]. These results suggest that bioactive compounds present in the methanolic extract of $L$. acida could induce (via the myometrial membrane receptors) the release of intracellular calcium. This moderate $\mathrm{Ca}^{2+}$ release induces the opening of the calcium channels thus causing an 
increase in the calcium flow at the origin of the contractions. These results are similar to those of Sharma et al. [37] who showed that histamine acts by first mobilizing calcium reserves and extracellular calcium.

\section{Conclusion}

Based on these findings, it appears that L. acida triggered uterine smooth muscle contraction in vitro. These uterotonic effects of $L$. acida are mediated through oxytocin receptors with mobilization of extracellular calcium. This result justifies the use of $L$. acida in traditional medicine to facilitate childbirth.

\section{Methods}

\section{Collection of plant material and preparation of extracts}

Fresh stem barks of L. acida (Anacardiaceae) were collected in January 2018 in the Noun Division (WestCameroun). A sample was authenticated at the Cameroon National Herbarium (HNC-IRA) by Mr. Victor Nana, by comparison to the specimen deposited under the voucher number $40942 \mathrm{HNC}$. The barks were shade-dried and grinded into powder prior to aqueous and methanolic extracts preparation.

\section{Extracts preparation}

To obtain the aqueous extract, $500 \mathrm{~g}$ of the plant powder were mix in $3 \mathrm{~L}$ of distilled water and boiled for 10 minutes. The solution was allowed to cool at room temperature and filtered using Whatman paper No 4. The filtrate was oven-dried to obtain $20.4 \mathrm{~g}$ of the aqueous extract (extraction yield: $4.08 \%$ ). The methanol extract was prepared by maceration of $250 \mathrm{~g}$ of the powder of $L$. acida stem barks in $1 \mathrm{~L}$ of methanol for $72 \mathrm{~h}$ at room temperature. The filtrate was evaporated under reduced pressure and ovendried to obtain $13.5 \mathrm{~g}$ of the methanol extract, giving an extraction yield of $5.4 \%$. For bioactivity investigations, the aqueous and methanol extracts were dissolved in distilled water.

\section{Animals}

Healthy non-pregnant adult female Wistar rats weighing 150-170 g were obtained from the animal house of the Department of Animal Biology, Faculty of Science of the University of Dschang-Cameroon. They were housed in plastic cages and had access to water and standard rat chow ad libitum. All procedures were validated by the scientific committee of the Department of Animal Biology, University of Dschang, which follows the internationally accepted standard ethical guidelines for laboratory animal use and care as described in the European Economic Community guidelines; EEC. 2010 Council Directive 2010/63/EU of 22 November 2010 [18].

\section{Experimental design}




\section{Isolated rat uterus preparation}

The preparation of estrogenized uterus was performed according to the procedure described by Watcho et al. [19]. Briefly, 24h before the experiment, virgin female rats were subcutaneously injected with 17- $\beta$ estradiol benzoate (13.28 nM per animal). To collect the uteri, animals were sacrificed by cervical dislocation under anesthesia and the uteri were promptly removed, cleaned of the connective tissue and cut into strips of about $1 \mathrm{~cm}$ of length. Each uterine strip was vertically mounted in an organ bath of 20 $\mathrm{mL}$ capacity containing fresh De Jalon solution of the following composition $(\mathrm{mM}): \mathrm{NaCl} 153.85, \mathrm{KCl}$ $5.64, \mathrm{CaCl} 20.55, \mathrm{MgSO} 40.08, \mathrm{NaOH} 12.5$ and glucose 2.78 , and thermostated at $37^{\circ} \mathrm{C}$. Strip tension was adjusted to $0.71 \mathrm{~g}$ and allowed to equilibrate for 45 min during which the physiological solution was changed every $15 \mathrm{~min}$. Spontaneous and drug-induced myometrial contractions were recorded using an isometric force transducer (SS12LA, BSL: Variable Force Transducer) connected to an MP36 amplifier (Biopac student lab pro version 3.7.3) and displayed on a monitor.

\section{Drugs challenges}

After the equilibration period during which spontaneous contractions were registered, non-cumulative concentration-response curves to oxytocin $\left(0.054-3 \times 10^{-10} \mathrm{~mol} / \mathrm{l}\right)$, acetylcholine $\left(2.13-17 \times 10^{-6} \mathrm{~mol} / \mathrm{l}\right)$, potassium chloride $(5.3-42.1 \mathrm{mmol} / \mathrm{l})$ and $L$. acida extract $(1.09-4.23 \mathrm{mg} / \mathrm{ml})$ were recorded during 5 min. The tissue was then washed by changing the bathing solution and allowed to rest for 15 min before the next stimulation. The experiment was repeated 5 times for each drug/extract concentration. At the end of this phase, the most active extract (methanol extract at lowest concentration) was chosen to investigate the mechanism of action of the plant uterotonic activity. Determination of the mechanism of

action of $L$. acida To determine the mechanism of action of $L$. acida, the tissue was pre-incubated for 30 min with atosiban $(2 \mu \mathrm{mol}$ ) (an oxytocin receptor inhibitor), atropine ( $1 \mu \mathrm{mol})$ (a specific type 3 muscarinic receptor antagonist) and nifedipine $(5 \mu \mathrm{mol})$ (an L-type calcium channel antagonist) before administration of oxytocin, acetylcholine and $\mathrm{KCl}$. The experiment was repeated with the plant extract in the presence of each antagonist. Furthermore, the effects of the plant extract was tested in the presence of 2-amino-ethoxyphenylborate (100 $\mu \mathrm{mol})$ (2-ADB, a specific antagonist of inositol 1,4,5-triphosphate receptors type 1$)$ and in free calcium medium containing EGTA ( $2 \mathrm{mmol})$ to investigate the involvement of the intracellular and extracellular calcium in the plant activity. The results were expressed as inhibition percentage and calculated as follows:Inhibition \% = (CF without antagonist-CF with in the presence of the antagonist) $/$ (CF without antagonist) $\times 100 \mathrm{CF}=$ contraction force. The calcium-free De Jalon solution was prepared by substitution of $\mathrm{CaCl}_{2}$ with EGTA as describe by Aziba[20].Drugs Estradiol benzoate (17- $\beta$-diol 3-benzoate), acetylcholine hydrochloride [ethanaminium, 2-(acetyloxy)-N,N,Ntrimethyl-, chloride], Potassium Chloride, EGTA(Ethylene glycol-bis (2-aminoethylether)-N,N,N',N'tetraacetic acid) and Atosiban were purchased from Sigma Chemical (St Louis, MO, USA). Atropine sulfate [a-(hydromethyl) benzene acetic 8-methyl-8-azabicyclo (3.2.1) oct-3yl-ester], oxytocin and nifedipine were purchased from local suppliers. All chemicals were dissolved in distilled water except 2APB (DMSO) [21]. 


\section{Statistical analysis}

The data was expressed as means \pm SEM. One-way analysis of variance (ANOVA) followed by Tukey HSD post hoc were used to assess statistical difference among groups using Statistica Software (version 8.0). The results were significantly different when $p<0.05$.

\section{Abbreviations}

2-ADB

2-Aminoethoxydiphenyl borate

EGTA

(ethylene glycol-bis( $\beta$-aminoethyl ether)-N,N,N',N'-tetraacetic acid)

CAPs

contraction-associated proteins

DAG

diacylglycerol

TRPC3

Transient Receptor Potential Cation Channel Subfamily C Member 3

PKC

Protein kinase $\mathrm{C}$

IP3

inositotrisphosphate

\section{Declarations}

\section{Acknowledgement}

The authors are grateful to the University of Dschang Cameroon, for the research facilities.

\section{Authors' Contributions}

Esther Ngadjui, Pierre Watcho,Jibril Yves Kouam and Georges Romeo Fozin Bonsou participated in the study design. Aimé Césaire Tetsatsi Momo, Jibril Yves Kouam and Patrick Brice Defo Deeh collected the data and carried out the statistical analysis. Pierre Watcho, Modeste Wankeu-Nya, Patrick Brice Defo Deeh and Telesphore Benoit Nguelefack drafted the manuscript. All authors read and approved the final manuscript.

\section{Funding}

The present work was carried out with authors' personal funds. 


\section{Availability of data and materials}

The data used to support the findings of this study are available from the corresponding author upon request.

\section{Ethics approval and consent to participate}

All procedures were validated by the scientific committee of the Department of Animal Biology, University of Dschang, which follows the internationally accepted standard ethical guidelines for laboratory animal use and care as described in the European Economic Community guidelines; EEC. 2010 Council Directive 2010/63/EU of 22 November 2010 [18].

\section{Consent for publication}

Not applicable

\section{Competing interests}

The authors declare that they have no competing interest.

\section{References}

1. Kuijsters NPM, Methorst WG, Kortenhorst MSQ, Rabotti C, Mischi M, Schoot BC. Uterine peristalsis and fertility: current knowledge and fucture perspective: a review and meta-analysis. Reprod Biomed Online. 2017;35:50-71.

2. Banciu A, Banciu DD, Mustaciosu CC, Radu M, Cretoiu D, Xiao J, Cretoiu SM, Suciu N, Radu BM. Beta estradiol regulates voltages-gated calcium channels and estrogen receptors in telocytes from human myometrium. Int J Mol Sci. 2018;19(5).

3. Corriveau S, Simon B, Nolin A, Rousseau E, Pasquier J. Levothyroxine treatment generates an abnormal uterine contractility patterns in an in vitro animal model. J Clin Transl Endocrinol. 2015;2:144-9.

4. Chelo D, Monehenimp F, Npanguepko F, Tietche F. Mortalité néonatale précoce et ses déterminants dans une maternité de niveau I à Yaoundé, Cameroun. Pan Afr Med J. 2012;13:1-12.

5. Vallera C, Choi LO, Cha CM, Hong RW. Uterotonic medications: Oxytocin, Methylergonovine, Carboprost, Misoprostol. Anesthesiol Clin. 2017;35:207-19.

6. Gomez LL, Marın-Gabriel MA, Encinas B, Cruz-Troca JJ, Rodríguez-Marrodán B. Oxytocin receptor antagonist (atosiban) in the threat of preterm birth: does it have any effect on breastfeeding in the term newborn. Breastfeed Med. 2018;13:123-8. 
7. Foumane P, Mve KV, Ze-Minkande J, Njofang NEA, Dohbit JS, Mboudou ET. Risk factors and prognosis of emergency cesarean delivery at the Yaoundé Women's and Children's Hospital Cameroon. Med Sante Trop. 2014;24:89-93.

8. Lawn JE, Blencowe H, Waiswa P, Amouzou A, Mathers C, Hogan D, Flenady V, Frøen JF, Qureshi ZU, Calderwood C,et al. Stillbirths: rates, risk factors, and acceleration towards 2030. Lancet. 2017;387:587-603.

9. Nkounkou-Loumpangou C, Binimbi-Massengo A, Nzonzi J, Ouamba JM, Abena AA, Diatewa M. Inventory of medicinal plants used in the treatment of female infertility in Brazzaville [Inventaire des plantesmédicinalesutiliséesdans le traitement de l'infertilitéféminine à Brazzaville]. Phytothérapie. 2005;6:252-9.

10. Bafor E, Sanni U. Uterine contractile effects of the aqueous and ethanol leaf extracts of Newbouldia laevis (Bignoniaceae) in vitro. Indian J Pharm Sci. 2009;71:124-7.

11. Monji F, Adaikan PG, Lau LC, Bin-Said B, Gong Y, Tan HM, Choolani M. Investigation of uterotonic properties of Ananas comosus extracts. J Ethnopharmacol. 2016;193:21-9.

12. Chakraborty I, Ghosal S, Pradhan N. Jussiaea repens (L) acts as an uterotonic agent - an in vitro study. Int J Pharm Sci Rev Res. 2015;27:368-72.

13. Ahmed M, Mabrouk M, Anuka J, Attahir A, Tanko Y, Wawata A, Yusuf M. Studies of the effect of methanolic stem bark extract of Lannea acida on fertility and testosterone in male Wistar rats. Asian J Med Sci. 2010;2:253-5.

14. Oumarou MR, Zingue S, Bakam BY, Ateba SB, Foyet SH, Tchaptchet-Mbakop FT, Njamen D. Lannea acida. Rich. (Anacardiaceae) ethanol extract exhibits estrogenic effects and prevents bone loss in an ovariectomized rat model of osteoporosis. Evid Based Complement Alternat Med. 2017;1-16 Article ID 7829059. doi:10.1155/2017/7829059.

15. Watcho P. Tetsatsi ASM, Wankeu-Nya M. Fozin GRB, Nguimatio FXK. Nkeng-Effouet PA, Nguelefack TB. Kamanyi A. Lannea acida improves the emission phases of ejaculation of mature male rate: effect on Vas deferens and seminal vesicles. Cam J Exp Sci. 2017;11: 54-60.

16. Muhaisan H. Chemical constituants from the bark of Lannea acida Rich (anarcadiaceae). Der Pharmachemical. 2013;5:88-96.

17. Solomon O, Azubuike MM, Hilter L, Oghenehevwe IE, Mary MA, Amos PI. Free radical scavenging activity and preliminary phytochemical screening of ethylacetate fraction of stem bark of Lanne aacida (A. Rich). J Nat Prod Resour. 2018;4:182-4.

18. EEC (2010). Directive 2010/63/EU of the European Parliament and of the Council of 22 September 2010 on the protection of animals used for scientific purposes. O. J.; L276:33-79.

19. Watcho P, Ngadjui E, Nkeng-efouet A, Nguelefack T, Kamanyi A. Evaluation of in vitro Uterotonic activities of fruit extracts of Ficus asperifolia in rats. Evid Based Complement Alternat Med. 2010;ID783413. doi:10.1093/ecam/nep221.

20. Aziba P. Effects of methanolic root extract of Ledebouria ovaltifolia (Hyacithaneae) on isolated smooth muscle preparation in rats. Afr J Biomed Res. 2008;11:323-7. 
21. Shu SJ, Lei XG, Liang JH, Song YH, Xu Q, Chen XD, Mao LG, Li ZG. The effects of second messenger cAMP and its relative components on the contraction of uterine smooth muscle of rat. Eur Rev Med Pharmacol Sci. 2017;21:1709-21.

22. Akah PA, Oli AN, Enwerem NM, Gamaniel K. Preliminary studies on purgative effect of Carica papaya root extract. Phytoterapia. 1997;68:327-31.

23. Bristol B. The contractile effects of Quillaja saponin on smooth muscle tissue isolated from the uterine horns of Mus musculus [B.S. thesis]. Bethel University, St. Paul, MN. 2017.

24. Liu J, Peng C, Zhou QM, Guo L, Liu ZH, Xiong L. Alkaloids and flavonoid glycosides from the aerial parts of Leonurus japonicus and their opposite effects on uterine smooth muscle. Phytochemistry. 2018;145:128-36.

25. Dehaan M, Degolier T. Raw ginger root juice (Zingiber officinale) produces a biphasic contractile response in isolated mouse uterine tissue under resting baseline tension. J Pharmacogn Phytochem. 2017;6:818-23.

26. Zeinad M, Ikram M, Amna E. Phytochemical screening contractile activity of Foeniculum vulgare seeds on rat intestine and uterine muscles. J Pharmacogn Phytochem. 2017;6:346-50.

27. Salleh N, Ahmad VN. In vitro effect of Ficus deltoidea on the contraction of isolated rat's uteri is mediated via multiple receptors binding and is dependent on extracellular calcium. BMC Complement Altern Med. 2013;13:359.

28. Sharma A, Nakade P, Choudhury S, Garg SK. Functional involvement of proteins kinase C, Rho-kinase and TRPC3 decreases while PLC increases with advancement of pregnancy in mediating oxytocininduced myometral contractions in water buffaloes (Bubalus bubalis). Theriogenology. 2017a;92:176-89.

29. Lorca RA, Prabagaran M, England SK. Functional insights into modulation of BKCa channel activity to alter myometrial contractility. Front Physiol. 2014;5:289.

30. Greenstein JL, Foteinou PT, Hashambhoy-Ramsay YL, Winslow RL. Modeling CaMKII-mediated regulation of L-type $\mathrm{Ca}^{2+}$ channels and ryanodine receptors in the heart. Front Pharmacol. 2014;5:60.

31. House SJ, Potier M, Basaillon J, Singer HA, Trebak M. The non-excitable smooth muscle: calcium signaling and phenotypic switching during vascular disease. Pflugers Arch. 2008;456:769-85.

32. Koli S, Prakash A, Choudhury S, Mandil S, Garg KS. Calcium channels, rho-kinase, protein kinase-C, and phospholipase-C pathways mediate mercury chloride-induced myometrial contractions in rats. Biol Trace Elem Res. 2018;187:418-24.

33. Daniel EE, El-Yazbi A, Cho WJ. Caveolae and calcium handling, a review and a hypothesis. J Cell Mol Med. 2006;10:529-44.

34. Saleem H, Tovey SC, Molinski TF, Taylor CW. Interactions of antagonists with subtypes of inositol 1,4,5-trisphosphate (IP3) receptor. Br J Pharmacol. 2014;171:3298-312.

35. Song T, Hao Q, Zheng Y, Liu QH, Wang XY. Inositol 1,4,5-trisphosphate activates TRPC3 channels to cause extracellular $\mathrm{Ca}^{2+}{ }^{2}$ flux in airway smooth muscle cells. Am J Physiol Lung Cell Mol Physiol. 
2015;309:1455-66.

36. Bencze M, Behuliaka M, Vavř́nová A, Zicha J. Broad-range TRP channel inhibitors (2-APB, flufenamic acid, SKF-96365) affect differently contraction of resistance and conduit femoral arteries of rat. Eur J Pharmacol. 2015;765:533-40.

37. Sharma A, Nakade P, Choudhury S, Yadav R, Garg K. Extra and intracellular calcium signaling pathways differentially regulate Histamine induced myometral contraction during early and midpregnancy stage in buffaloes (Bubalus bibalis). Anim Reprod Sci. 2017b;179:10-9.

\section{Figures}



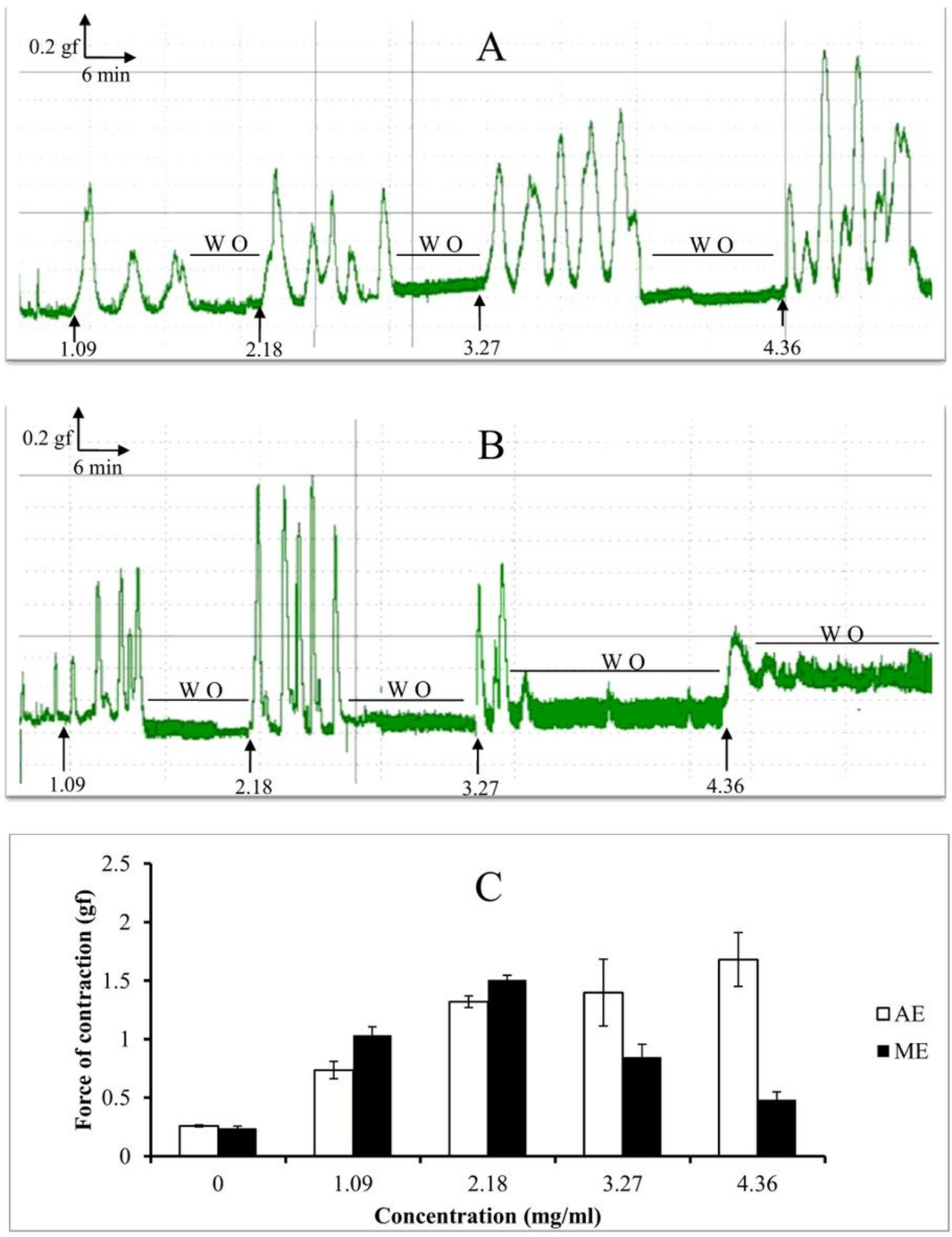

Figure 1

Effects of aqueous (A) and methanolic (B) extracts of $\mathrm{L}$. acida on isometric uterine contractions. C: mean force contraction generated from five isolated uterine horns obtained from different oestrogenized rats, which were exposed to various concentrations of $L$ acida $(0 ; 1.09 ; 2.18 ; 3.27$ and $4.36 \mathrm{mg} / \mathrm{ml}) \mathrm{W} 0=$ washout period, $\mathrm{AE}=$ aqueous extract, $\mathrm{ME}=$ methanolic extract. 

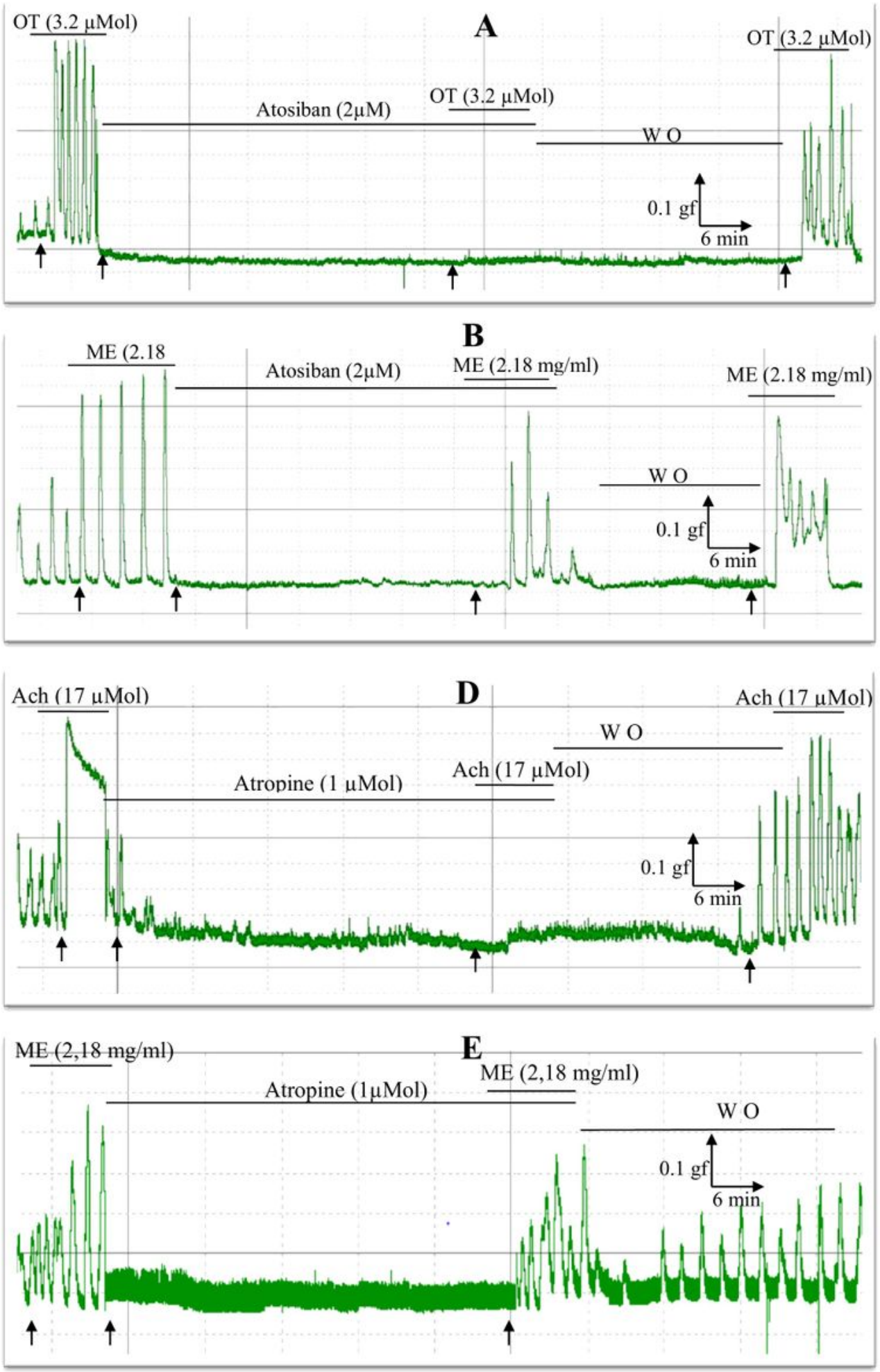
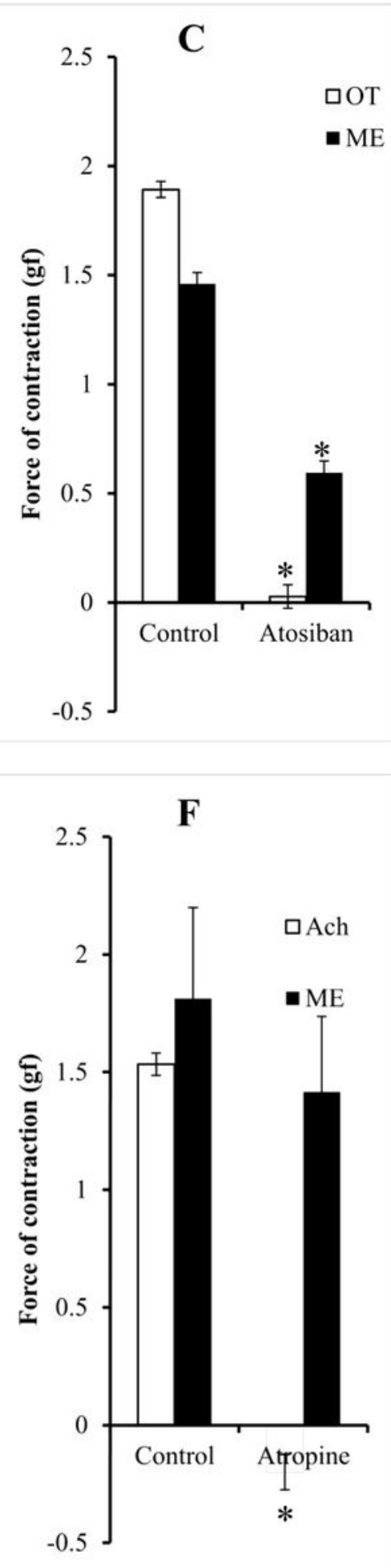

\section{Figure 2}

Effect of methanolic extract of $L$. acida and agonists in the presence of selected antagonists. $(a, b)$ Representative tracings of isometric uterine contraction following agonists (a) and L. acida (b) administration in the presence of various antagonists and (c) mean Emax following administration of agonist sand L. acida. $\mathrm{n}=5$ rats per group, $\mathrm{ME}=$ methanolic extract; $\mathrm{OT}=$ oxytocin; $\mathrm{Ach}=$ acetylcholine; $\mathrm{W}$ O= washout period. *: $p<0.05$ compared to control. 

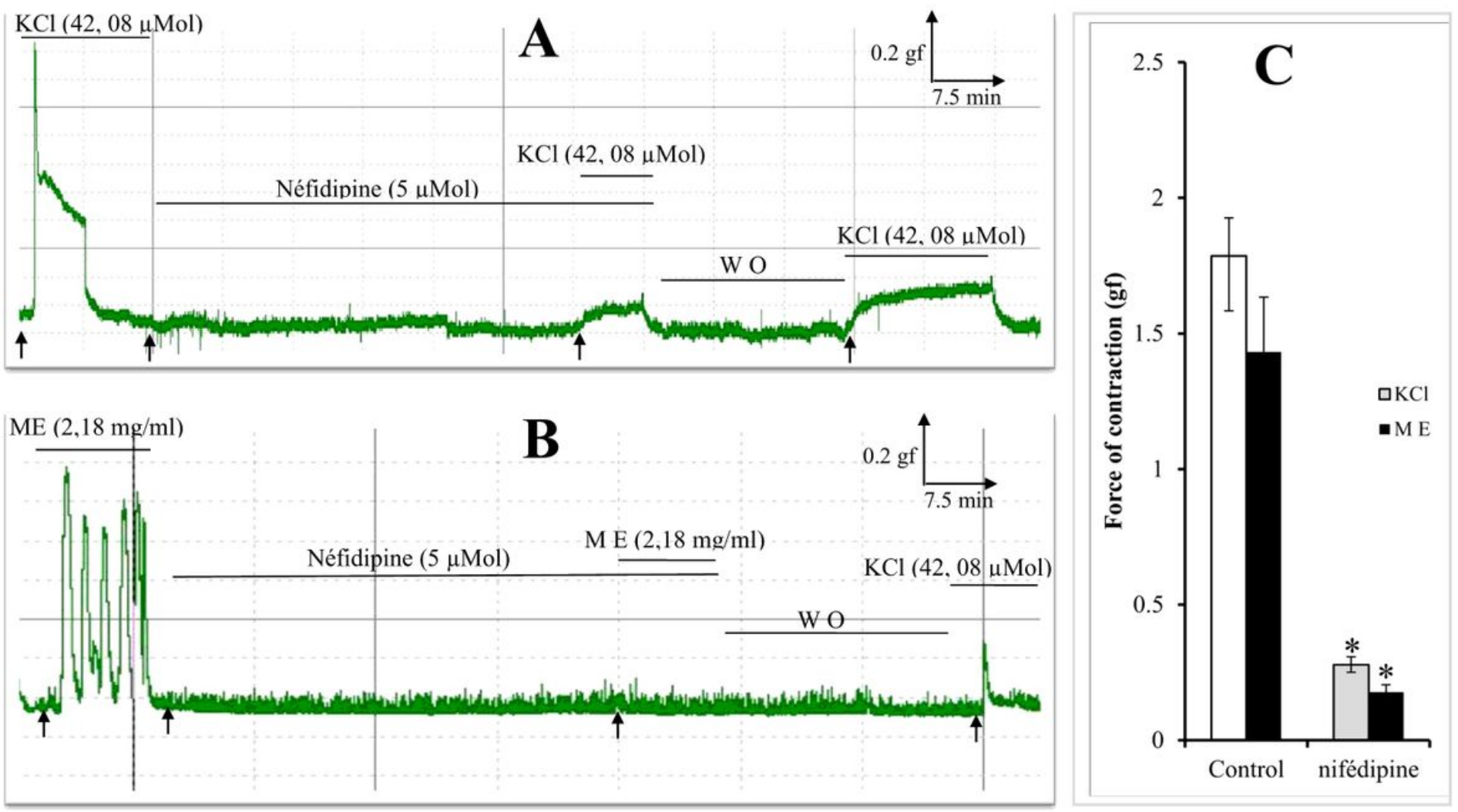

Figure 3

Effect of potassium chloride and methanolic extract of $L$. acida in the presence of nifedipine. $(A, B)$ Representative tracings of isometric uterine contraction following potassium chloride and $\mathrm{L}$. acida administration in the presence of antagonists and (C) mean Emax following administration of L. acida at $2.18 \mathrm{mg} / \mathrm{ml}$ and agonists alone and in the presence of nifedipine. $\mathrm{n}=5$ rats per group, $\mathrm{ME}=$ methanolic extract; $\mathrm{KCl}=$ Potassium chloride. $\mathrm{W} \mathrm{O}=$ washout period. 

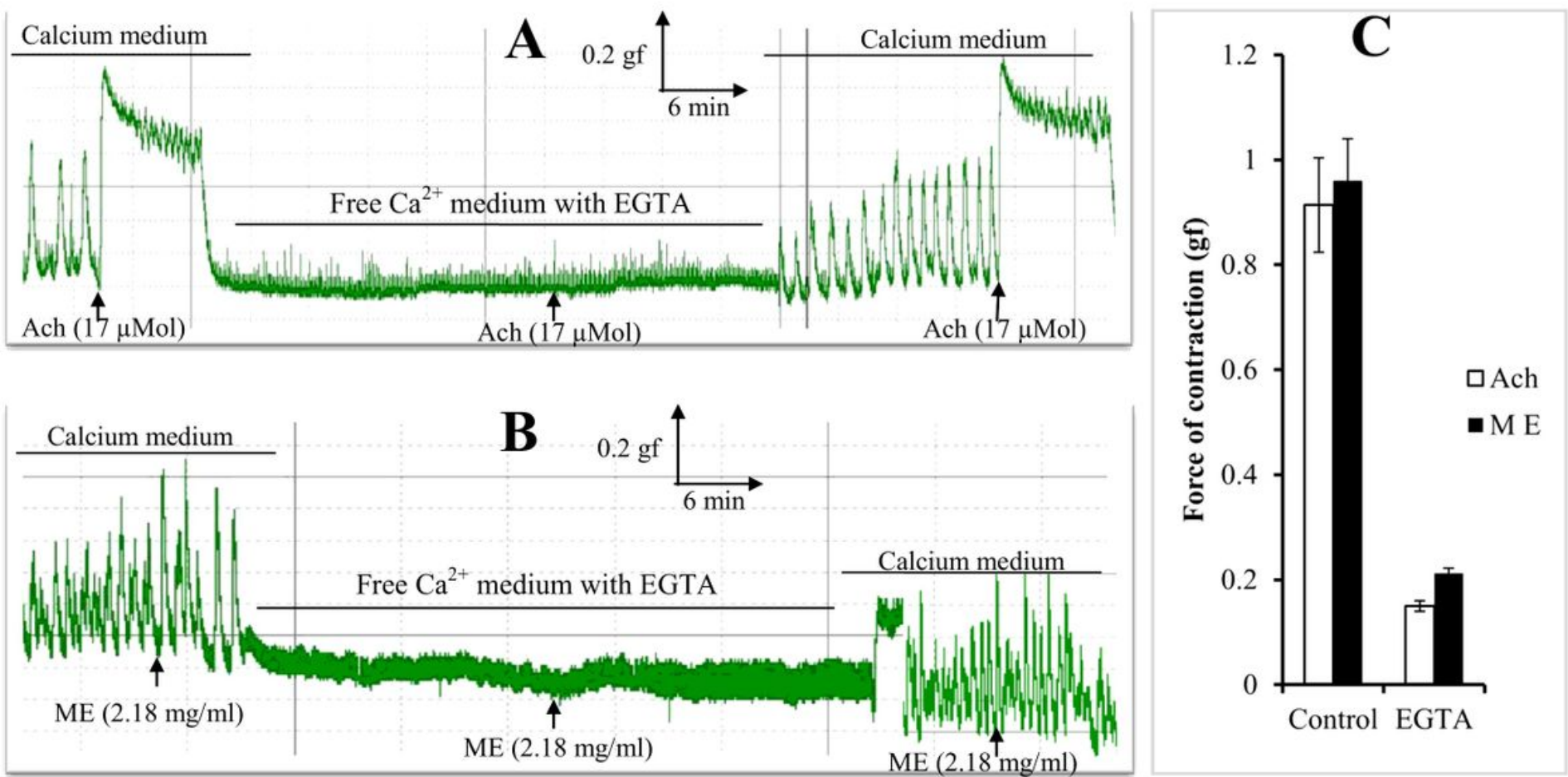

\section{Figure 4}

Representative physiographic recording of acetylcholine (A) and L. acida (B) De Jalon and in free-Ca2+ solution with EGTA on myometrial rat strips. Chart (C) shows the Emax of acetylcholine and L. acida drugs administrated in De Jalon and in free $\mathrm{Ca} 2+$ solution. L. acida have any effect without Ca2+.
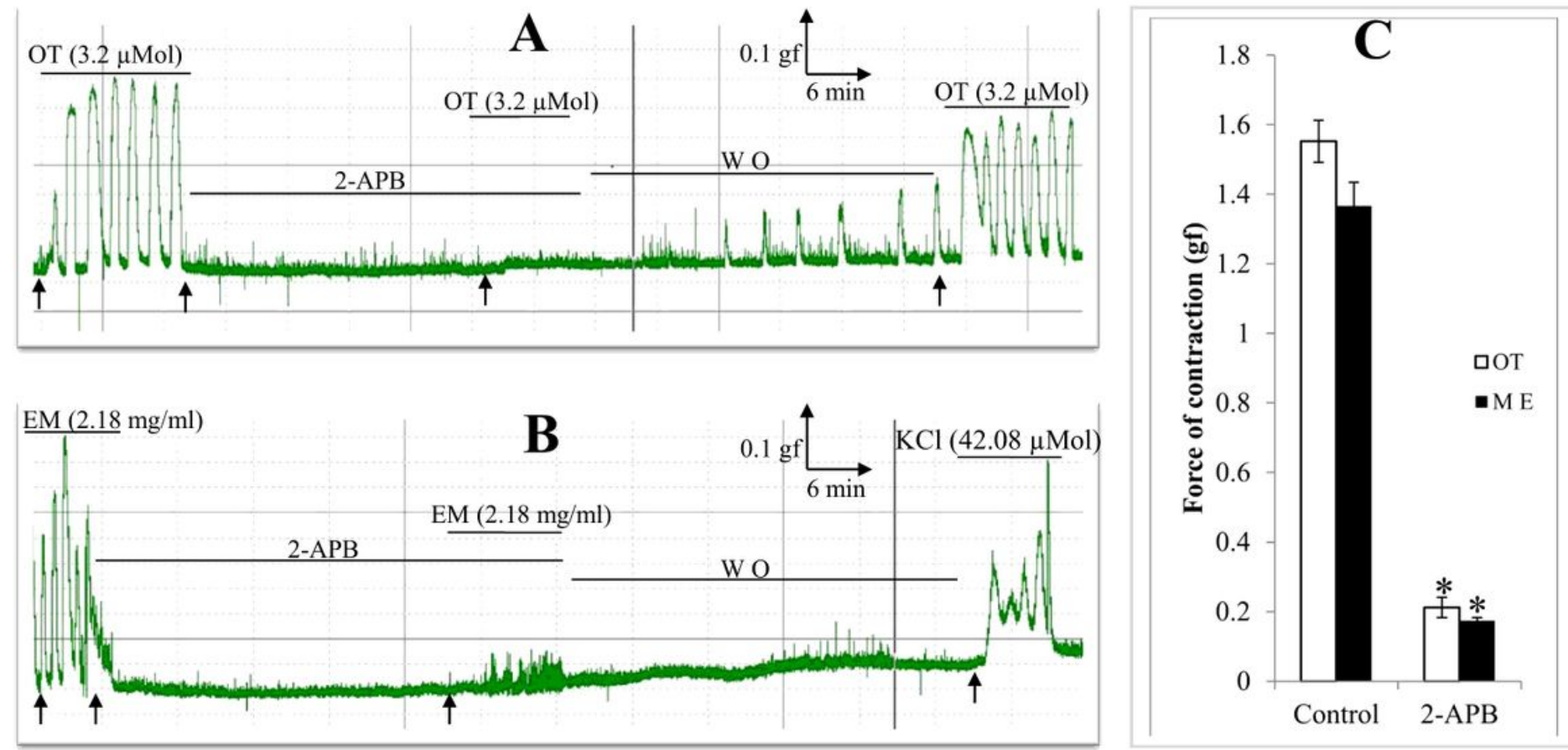

Figure 5 
Effect of IP3 receptors blocker on uterine contraction induced by oxytocin (A) and methanolic extracts of L. acida (B). (C) Show the chart of oxytocin and L. acida drugs administrated. OT= ocytocine and ME = methanolic extract. $\mathrm{W} \mathrm{O}=$ washout period. 